\title{
FAKTOR RISIKO PEMUNCULAN AGRESI DAN PELANGGARAN MORAL PADA REMAJA DI LEMBAGA PEMBINAAN KHUSUS ANAK
}

\author{
Naomi Soetikno ${ }^{1}$, P. Tommy S. Suyasa ${ }^{2}$ dan Florencia Irena ${ }^{3}$ \\ ${ }^{1}$ Fakultas Psikologi, Universitas Tarumanagara \\ Email: naomis@fpsi.untar.ac.id \\ ${ }^{2}$ Fakultas Psikologi, Universitas Tarumanagara \\ Email: tommys@fpsi.untar.ac.id \\ ${ }^{3}$ Fakultas Psikologi, Universitas Tarumanagara \\ Email: florenciairena@ymail.com
}

\begin{abstract}
ABSTRAK
Remaja yang melakukan pelanggaran hukum seperti berbuat agresi yang mengakibatkan kematian, atau pelanggaran moral seperti perkosaan, maupun penyalahgunaan obat/narkotika dikenakan hukuman yang membawa mereka di Lembaga Pemasyarakatan. Lembaga pemasyarakatan khusus anak atau disebut sebagai Lembaga Pembinaan Khusus Anak (LPKA) berada di berbagai wilayah di Indonesia, salah satunya di Tangerang. Selama di dalam LPKA, anak didik (andikpas) disana masih sering juga melakukan pelanggaran aturan, seperti perilaku agresi, penyebaran terror, dan juga pelanggaran moral. LPKA membutuhkan adanya instrument untuk klasifikasi perilaku andikpas sehingga dapat membantu dalam menentukan tingkat pengamanan dan pengawasan yang diberikan dari tingkat minimum sampai pada maksimun pengamanan. Berpijak dari kebutuhan mitra mengenai adanya instrument yang dapat mengklasifikasikan perilaku pelanggaran andikpasmaka penelitian ini bertujuan untuk mendapatkan infromasi mengenai factor risiko andikpas melakukan pelanggaran agresi dan moral di dalam LPKA. Metode yang digunakan adalah focused group discussion pada petugas dan andikpas. Didapatkan hasil bahwa adanya factor internal dari andikpas yang menjadi factor risiko pemunculan agresi dan pelanggaran moral juga factor eksternal dari petugas, system, aturan, dan pengawasan, dan juga interaksi dengan sesame andikpas.
\end{abstract}

Kata kunci: Agresi; Lembaga Pembinaan Khusus Anak; Moral; Remaja.

\section{PENDAHULUAN}

Anak dan remaja dalam interaksinya dengan lingkungan social seringkali mengalami permasalahan yang sampai terjadi pelanggaran aturan hokum. Perilaku penggaran hokum yang dilakukan dapat menjerat anak dan remaja dalam pasal pidana sehingga masuk kedalam Lembaga Pemasyarakatan. Dalam Pasal 1 Angka 1 UU Nomor 12 Tahun 1995 tentang Pemasyarakatan, Pemasyarakatan adalah kegiatan untuk melakukan pembinaan Warga binaan Pemasyarakatan berdasarkan sistem, kelembagaan dan cara pembinaan yang merupakan bagian akhir dari system pemidanaan dalam tata peradilan pidana. Dari pengertian tersebut dapat diketahui bahwa inti dari pemasyarakatan adalah pembinaan terhadap narapidana supaya nantinya dapat kembali ke masyarakat dengan baik (Nashriana, 2012). Lembaga Pemasyarakatan Khusus Anak (selanjutnya LPKA) menampung anak yang berhadapan dengan hukum yakni anak yang berkonflik dengan hukum. Anak yang berhadapan dengan hukum ini adalah anak yang telah berusia 12 sampai dengan 18 tahun (UU Peradilan Anak no 11 tahun 2012).

Selama berada di LPKA, anak didik disana (selanjutnya disebut andikpas) menajalni proses pembinaan. Adapun dalam pembinaan andikpas terdapat beberapa asas yang menjadi pedoman yakni asas pengayoman, asas persamaan perlakuan dan pelayanan, asas pendidikan, asas pembimbingan, asas penghormatan harkat dan martabat manusia, asas terjaminnya hak untuk tetap berhubungan dengan keluarga dan orang-orang tertentu (Nashriana, 2012). Dapat diambil kesimpulan bahwa asas pembinaan pemasyarakatan adalah dengan memberikan bekal hidup 
kepada warga binaan agar nanti menjadi berguna di dalam masyarakat, memberikan persamaan perlakuan dan pelayanan di dalam lapas, memberikan pendidikan baik dalam bidang keterampilan, kekeluargaan, dan kerohanian. Terakhir adalah mengijinkan narapidana untuk bertemu dengan keluarga dan kerabat yang lain. Hal ini diharapkan dapat memberi semangat kepada narapidana selama hidup di Lapas.

Berada di LPKA pada beberapa andikpas ternyata tidak menyurutkan kecenderungannya berperilaku melanggar aturan moral maupun melakukan aksi agresi. Permasalahan yang terjadi pada andikpas adalah masih terdapatnya perilaku yang melanggar aturan di dalam lapas seperti pencurian, perkelahian, saling mengejek/ bullying, membawa handphone yang sebenarnya dilarang, merokok, bahkan melakukan pelanggaran yang dinilai tidak bermoral yakni adanya aktivitas seksual yang tidak sepantasnya (personal komunikasi dengan petugas pembinaan andikpas di LPKA Tangerang, September 2018). Perilaku melanggar aturan disebabkan oleh banyak faktor, seperti diketahui bahwa regulasi emosi dan juga regulasi diri yang rendah (Carlo et al, 2012; Kemp et al, 2017; Kim, 2017), faktor kepribadian (Archer, 2009; Carlo et al, 2012). Tindakan melawan aturan sering ditampilkan dalam bentuk agresi, berbagai macam perilaku yang ditampilkan baik berbentuk verbal maupun non-verbal. Agresi merupakan perilaku yang bertujuan untuk menyakiti orang lain. Perilaku agresi berkaitan dengan faktor bawaan, faktor hasil interaksi dengan lingkungan, juga mekanisme berpikir (Archer, 2009). Bentuk agresi sangat berkaitan dengan keyakinan pemikiran yang dimiliki (Bailey \& Ostrov, 2008), juga kontrol diri (Denson et al, 2011).

Agresi yang dilakukan serta pelanggaran aturan norma terkait juga dengan moral yang ada pada remaja. Moral merupakan pengetahuan yang menyangkut budi pekerti individu yang beradab, juga berarti ajaran baik-buruk tindakan, dan kelakukan (akhlak). Moralitas adalah membahas tentang 'bagaimana seharusnya kita hidup' dan 'mengapa demikian' (James Rachels, 2003). Anak dan remaja mempelajari moral dari hasil interaksinya dengan lingkungan selama masa perkembangannya. Berdasarkan pandangan behavioral-kognitif perkembangan moral adalah kelangsungan mempelajari apa standar moral serta norma sosial; menentukan bagaimana dan bilamana standar moral dan nilai sosial itu dilaksanakan, oleh siapa dan terhadap siapa serta konsekuensi apa yang mungkin dibawakannya, baik secara langsung maupun tidak langsung. Individu dapat mengambil pelajaran bahwa individu yang diharapkan garis besar pandangan moralnya atau mengambil manfaatnya dalam situasi-situasi tertentu dan dapat pula belajar dari berbagai situasi yang dialaminya.

Pelanggaran aturan di LPKA dengan adanya aksi agresi dan pelanggaran moral yang dilakukan andikpas menjadi keprihatinan bagi pemenuhan asas-asas yang ada dalam pembinaan andikpas. Selama didalam LPKA, andikpas berinteraksi satu dengan lainnya, berinteraksi yang dapat saling memberi pengaruh satu sama lain. Untuk menjaga agar tidak memengaruhi andikpas yang lain, maka pembinaan di LPKA membuat aturan mengenai intensitas dan bentuk pengawasan maksimum terhadap andikpas yang memiliki kecenderungan atau berpotensi melakukan pelanggaran. Dalam hal membuat penilaian terhadap potensi andikpas yang memiliki potensi perilaku agresi dan pelanggaran moral, LPKA membutuhkan bantuan.

Pemunculan agresi dan pelanggaran moral yang dilakukan individu umumnya dipengaruhi oleh berbagai factor risiko. Factor risiko dalam pemunculan suatu perilaku dapat ditinjau dari dua sisi yakni sisi individual dan sisi lingkungan. Aspek individu yang ada pada remaja yang melakukan 
aksi agresi dan pelanggaran moral terkait dengan perkembangan yang terjadi didalam dirinya. Perkembangan remaja mencakup perkembangan biologis, kognisi, dan sosio-emosinya. Faktor biologis akan berubah pada saat individu mengalami pubertas. Pubertas merupakan tanda dari berakhirnya masa kanak-kanak. Pada saat individu mengalami purbertas, maka individu akan mengalami pertumbuhan tinggi dan berat yang cepat, perubahan proporsi tubuh dan bentuk tubuh, dan perkembangan kematangan seksual (Papalia et al., 2010). Remaja memasuki perkembangan kognitif tertinggi yaitu formal operation yaitu perkembangan kognitif dengan kemampuan berpikir abstrak. Piaget dalam Papalia et al, 2013 menjelaskan kemampuan berpikir formal operasional ditunjukkan oleh beberapa ciri utama yaitu (1) berpikir abstrak yaitu mampu memikirkan sesuatu tanpa harus melihat benda fisiknya; (2) berpikir hipotetik-deduktif yaitu menyusun hipotesis dan menarik kesimpulan baru berdasarkan kebenaran umum; (3) berpikir silogistik yaitu menarik kesimpulan baru berdasarkan premis universal yang ada sebelumnya; (4) berpikir proposional yaitu satu bentuk silogisme yang lebih variatif dan kompleks berdasarkan kemungkinan yang ada. Remaja juga menunjukkan berkembangnya penalaran moral Postkonvensional, di mana seseorang sudah mengikuti prinsip moral internal dan dapat memutuskan di antara standar moral yang berlawanan. Orang-orang pada tahap ini menyadari konflik antara standar moral dan membuat keputusan sendiri berdasarkan prinsip hak, kesetaraan, dan keadilan (Santrock, 2005). Dalam perkembangan sosio-emosinya, berkembang aspek psikososial remaja yakni identitas diri. Erikson menjelaskan bahwa remaja mencapai tahap identity vs identity confusion yaitu tahap untuk mengembangkan perasaan dirinya termasuk peran yang akan dimainkan di dalam masyarakat (Papalia et al., 2013). Menurut Erikson (dikutip oleh Papalia et al., 2013) remaja membentuk dirinya bukan berdasarkan modeling terhadap dirinya yang dulu melainkan memodifikasi identitas sebelumnya.

Aspek lingkungan berperan pada perkembangan dan perilaku anak dan remaja. Perkembangan individu merupakan interaksi antara individu yang berkembang dengan lingkungannya, yang merupakan perubahan dalam cara individu tersebut mengamati dan menghadapi lingkungan (Bronfenbrenner, 1979). Lebih lanjut Bronfenbrenner (1979) mengungkapkan bahwa lingkungan sosial merupakan suatu rangkaian sistem sosial yang mempunyai derajat pengaruh langsung yang berbeda terhadap perkembangan individu. Taraf yang berperan langsung pengaruhnya terhadap perkembangan individu disebutnya dalam sistem micro, berupa rumah, kelas yang merupakan tata letak tunggal; dimana hubungannya berupa tatap muka seperti interaksi antara orang tua dan anak, atau interaksi antara guru atau dosen dan siswanya. Taraf yang kedua adalah yang disebutnya sistem meso yaitu interaksi yang terjadi antar sistem micro ; misalnya interaksi antar orang tua dan guru (rapat) tentang anak, dimana anak dilibatkan dan dipengaruhi langsung oleh rapat tersebut. Taraf ketiga adalah sistem ekso, yaitu suatu interaksi dimana anak tidak langsung dilibatkan tetapi berpengaruh terhadap anak; misalnya pekerjaan orang tua menentukan status sosial anak tersebut. Taraf keempat adalah sistem makro, yaitu pengaruh kebudayaan, ideologi yang mempunyai peranan dalam kehidupan individu. Pengaruh lingkungan sosial tersebut sebagai suatu yang relatif konstan, khususnya selama kurun waktu tertentu dari periode kehidupan; misalnya periode bayi, anak, remaja, dan dewasa. Dalam arti lingkungan tidak hanya punya struktur tetapi juga punya makna. Lingkungan yang berbeda dalam pengaruh atau lingkungan yang sama dalam waktu yang berbeda dapat berubah dalam maknanya dan membangkitkan perubahan pada tindakannya.

Konsep mengenai lingkungan berdasarkan teori Lewin (dalam Joefiani, 2013) mengenai Life Space. Konsep Life Space dalam hal ini melibatkan tidak saja lingkungan sosial dan budaya tapi juga lingkungan fisik. Beberapa istilah dipakai untuk menguraikan lingkungan secara umum, yaitu pengertian objek, situasi atau orang lain dalam life space; individu dapat memberikan valensi 
positif atau negatif tergantung dari kemampuan untuk mengurangi dan menambah secara berangsur-angsur kebutuhan atau tujuan dari individu tersebut.

\section{Hasil Identifikasi dan Rumusan Masalah}

Hasil Identifikasi : Memerhatikan permasalahan mitra yakni Lembaga Pemasyarakatan Khusus Anak Pria di Tangerang, secara umum dapat dirumuskan sebagai berikut:

1) adanya kebutuhan untuk mengklasifikasikan andikpas yang memerlukan pengawasan dan pembinaan tingkat minimum dan maksimum;

2) adanya andikpas yang menampilkan perilaku pelanggaran aturan yakni perilaku agresi dan pelanggaran moral;

3) belum adanya instrumen yang dimiliki oleh pembinaan di LPKA yang dapat mengklasifikasikan permasalahan perilaku dari andikpas.

Rumusan Masalah : Memerhatikan permasalahan mitra yakni Lembaga Pemasyarakatan Khusus Anak Pria di Tangerang, secara umum dapat dirumuskan bahwa asesmen dan pengklasifikasian andikpas perlu dilakukan untuk menunjang pembinaan selama di LPKA, dan belum adanya atribut pemeriksaan atau asesmen yang dimiliki oleh LPKA. Langkah-langkah yang diperlukan adalah sebagai berikut:

1) dilakukannya penggalian informasi dari andikpas maupun dari petugas pembinaan dan penjagaan mengenai perihal mana yang menjadi faktor risiko andikpas sampai terjadinya perilaku agresi dan pelanggaran moral. Kegiatan penggalian informasi ini dilakukan melalui teknik focused group discussion sehingga mendapatkan rumusan yang disepakati bersama.

2) hasil dari focused group discussion akan dirumuskan dalam definisi operasional dan indikator perilaku yang dicocokkan dengan teori-teori Psikologi.

\section{METODE}

Partisipan/penerima jasa: Andikpas di LPKA Pria di Tangerang, usia 12-18 tahun serta guru di sekolah istimewa LPKA dan petugas bagian pembinaan dan penjagaan.

Metode pelaksanaan: Focused group discussion.

Dilakukan dua kali FGD yakni untuk andikpas dan untuk guru serta petugas.

Andikpas disatukan dalam kelompok yang berisikan maksimum 10 peserta, demikian pula guru dan Petugas disatukan dalam kelompok yang berisikan maksimum 10 peserta.

Focus Group Discussion (atau FGD) adalah metode penelitian kualitatif dalam ilmu sosial, dengan penekanan dan penerapan khusus dalam lingkup evaluasi program perkembangan.

FGD adalah wawancara semi-terstruktur yang telah ditentukan yang dipimpin oleh seorang moderator yang ahli. Moderator mengajukan pertanyaan luas untuk mendapatkan tanggapan dan menghasilkan diskusi di antara para peserta. Tujuan moderator adalah untuk menghasilkan jumlah diskusi dan pendapat maksimum dalam jangka waktu tertentu.

Waktu pelaksanaan FGD adalah 2 kali pertemuan, yakni pertemuan dengan andikpas yang terpisah dengan pertemuan dengan petugas. Setiap pertemuan membutuhkan waktu paling lama adalah 3 jam.

Instrumen yang dibutuhkan: alat tulis, informed consent.

Aktivitas pada FGD mencakup diskusi materi secara berkelompok, perumusan hasil kegiatan. 


\section{HASIL DAN PEMBAHASAN}

Berdasarkan FGD yang telah dilakukan di LPKA Tangerang, terdapat beberapa bentuk perilaku agresi dan pelanggaran moral yang dilakukan andikpas, yaitu agresi verbal (berupa kata-kata kasar, tidak sopan, atau ancaman), agresi fisik (berupa pemukulan dengan tangan kosong atau barang dan saling mendorong), pemerasan (benda-benda yang dimiliki atau uang), kepemilikan benda terlarang (uang, senjata tajam, handphone, serta benda-benda lain), pemberian suap kepada sebagian petugas, pembuatan senjata tajam di dalam LPKA, dan pelanggaran ringan seperti membolos sekolah, merokok, dan terlambat apel.

Berdasarkan FGD dari andikpas dan petugas, ditemukan tujuh faktor yang berpotensi meningkatkan risiko terjadinya perilaku agresi dan pelanggaran moral pada andikpas. Pertama, kegiatan kunjungan yang dapat diintervensi oleh andikpas lain. Andikpas memiliki hak untuk menerima kunjungan di waktu-waktu tertentu yang telah ditetapkan LPKA. Pada umumnya, andikpas menerima buah tangan seperti makanan, barang-barang keperluan pribadi, atau uang saat dikunjungi. Sesama andikpas diharapkan berbagi sehingga ketika ada andikpas yang tidak bersedia membagi apa yang diperolehnya dari kunjungan, dapat menimbulkan ketidaksukaan di kalangan andikpas lain. Selain itu, perilaku andikpas lain yang mengganggu waktu kunjungan (seperti meminta benda yang dibawakan) juga dapat menimbulkan perasaan tidak senang pada andikpas yang sedang dikunjungi.

Kedua, adu domba yang dilakukan oleh sesama andikpas kepada andikpas tertentu yang tidak disukai. Di dalam LPKA, andikpas tinggal di lokasi yang terbatas sehingga sangat rentan terjadi gesekan-gesekan di antara andikpas sendiri. Ketika ada andikpas yang menjelek-jelekkan andikpas lain, maka gesekan yang terjadi dapat berubah menjadi perkelahian fisik, adu mulut (agresi verbal), atau tindakan lainnya.

Ketiga, suasana hati atau kondisi fisik andikpas. Hampir seluruh andikpas yang berada di LPKA berada dalam usia remaja. Sementara salah satu ciri khas pada remaja adalah terjadinya fluktuasi hormon yang dapat memengaruhi perubahan suasana hati. Ketika ada andikpas yang sedang berada dalam suasana hati negatif, hal yang sifatnya netral atau tidak sengaja dilakukan andikpas lain dapat menjadi pemicu terjadinya luapan emosi yang berlebihan. Hal yang sama juga terjadi pada andikpas yang sedang lelah, kepanasan, atau sakit.

Keempat, kecenderungan andikpas untuk bercanda secara berlebihan. Biasanya hal ini diawali dengan bercanda di antara sesama andikpas. Namun ketika ada andikpas yang menimpali secara berlebihan, andikpas lain merasa tersinggung. Sebagian andikpas memiliki kecenderungan untuk mempertahankan kehormatan atau harga dirinya tanpa mempertimbangkan dampak dari perbuatannya. Sementara andikpas yang membuat tersinggung kadangkala tidak merasa bersalah atau tidak menyadari apa yang sudah dilakukannya.

Kelima, andikpas lain menghambat tugas yang sedang dikerjakan (dengan sengaja atau tanpa disadari). Di LPKA, andikpas memiliki tanggung jawab yang harus diselesaikan. Terdapat beberapa penanggung jawab (dikenal dengan istilah tahanan pendamping atau tamping) yang bertugas mengawasi andikpas lain dalam menyelesaikan tugas-tugasnya dan melaporkan ke petugas apabila ada masalah. Pada umumnya, tamping (khususnya tamping blok) didengarkan oleh andikpas yang diawasinya. Tetapi ketika tamping sedang tidak berada di lokasi kegiatan, kadangkala ada andikpas yang dengan sengaja (misalnya menolak membersihkan kolam saat tugas piket) atau tanpa sengaja (misalnya menginjak lantai yang baru dibersihkan) menghambat tugas yang sedang dikerjakan sehingga menyebabkan andikpas yang sedang bertugas merasa kesal dan meluapkan kekesalannya dengan cara yang kurang tepat.

Keenam, riwayat kehidupan andikpas sebelum masuk LPKA. Andikpas berasal dari latar belakang yang beragam, di antaranya kehidupan di jalan yang tidak terbiasa dengan peraturan, penggunaan kekerasan sebagai cara menyelesaikan persoalan, atau penggunaan bahasa yang kasar. Ketika 
masuk ke LPKA, kebiasaan-kebiasaan tersebut masih melekat pada andikpas sehingga petugas melihat sebagian andikpas sulit untuk menyesuaikan dengan kondisi di LPKA atau terlibat konflik akibat kebiasaan yang tidak dapat diterima oleh andikpas lain. Sebagian andikpas juga telah terpapar kekerasan baik sebagai korban maupun pelaku sehingga rentan untuk kembali terlibat dalam kasus kekerasan di LPKA. Selain itu, sebagian andikpas memiliki keterampilan untuk membuat senjata tajam dari benda-benda yang tersedia, seperti sikat gigi atau besi teralis.

Ketujuh, paparan terhadap seksualitas. Sebagian andikpas telah aktif secara seksual sebelum masuk LPKA sehingga ada kecenderungan untuk melakukan aktivitas seksual selama berada di LPKA, baik yang melibatkan diri sendiri ataupun orang lain. Sejauh ini petugas melihat kejadian yang berkaitan dengan seksualitas sudah jauh berkurang di kalangan andikpas tetapi meyakini tetap ada aktivitas seksual yang tidak teridentifikasi.

Ketujuh faktor tersebut berkaitan erat dengan regulasi emosi, impulsivitas, dan empati. Apabila andikpas memiliki kemampuan meregulasi emosi yang baik, maka andikpas tidak akan mudah terprovokasi oleh perilaku atau perkataan dari andikpas lain. Hal ini dapat meminimalkan terjadinya perkelahian di kalangan andikpas. Kecenderungan berperilaku impulsif juga berkaitan dengan pelanggaran peraturan di LPKA. Andikpas yang impulsif cenderung bertindak secara spontan, tanpa memikirkan dampak atau konsekuensi dari perbuatannya. Adapun kemampuan berempati dapat membantu andikpas untuk memahami apa dampak yang ditimbulkan dari perilakunya terhadap orang lain sehingga ia dapat menahan diri untuk tidak memberikan komentar atau pernyataan yang tidak menyenangkan bagi orang lain. Andikpas juga dapat memetik manfaat dari pelatihan asertivitas dan team building secara berkala yang diharapkan dapat mengurangi risiko saling mengadu domba atau dengan sengaja menghambat tugas anak lain di antara andikpas. Selain ketujuh faktor risiko tersebut, juga ditemukan beberapa faktor yang dinilai memengaruhi terjadinya perilaku agresi dan pelanggaran moral pada andikpas. Pertama, kurangnya kontrol dari petugas atau pembiaran ketika andikpas melakukan pelanggaran. Berdasarkan teori perkembangan moral Kohlberg, diduga sebagian besar andikpas masih berada dalam tahap pertama perkembangan moral, di mana mereka akan menampilkan perilaku positif untuk mendapatkan reward dari lingkungan dan untuk menghindari hukuman. Akibatnya, ketika tidak ada petugas yang mengawasi, andikpas cenderung lebih berani untuk melakukan pelanggaran.

Kedua, contoh dari petugas. Andikpas menilai terdapat sebagian petugas yang tidak memberikan teladan dalam bersikap jujur dan rajin. Hal ini membuat motivasi andikpas untuk bersikap baik sesuai arahan petugas menjadi rendah karena kurangnya respect terhadap petugas tersebut. Peran lain dari petugas adalah menitipkan uang tunai untuk berbelanja di koperasi sekalipun ada sistem kupon untuk mencegah andikpas memegang uang tunai. Hal ini menjadi celah yang sering dimanfaatkan andikpas untuk menggunakan uang tunai di LPKA.

Ketiga, jumlah andikpas yang banyak di dalam sebuah kamar. Kamar yang paling besar di LPKA Tangerang berkapasitas sebanyak 39 orang andikpas. Hal ini berpotensi menimbulkan terjadinya pelanggaran dan munculnya perilaku agresi di kalangan andikpas, khususnya pada andikpas yang relatif baru berada di LPKA.

Keempat, ketersediaan bahan yang dapat dijadikan senjata tajam di dalam LPKA. Sebagian andikpas sudah memiliki keterampilan untuk membuat senjata tajam sejak sebelum masuk ke LPKA. Oleh sebab itu, mereka mampu untuk mengubah benda-benda yang ada di sekitar seperti sikat gigi dan besi teralis menjadi senjata tajam yang dapat digunakan untuk melakukan pelanggaran dan mendukung perilaku agresi.

Kelima, saling meniru di antara andikpas atau dari film, buku, maupun permainan terkait pelanggaran peraturan. Petugas melihat ada pengaruh film, buku, atau permainan terhadap pelanggaran peraturan, khususnya yang memberikan ide kepada andikpas untuk melakukan pelanggaran seperti berkelahi atau melarikan diri dari LPKA. Selain itu, ada indikasi andikpas 
melakukan perilaku agresi dan pelanggaran moral karena melihat contoh yang dilakukan oleh andikpas lain, sehingga tercipta 'standar moral' tersendiri di kalangan mereka terkait apa yang boleh dan tidak boleh dilakukan di dalam LPKA.

Dasar pemikiran dilakukannya focused group discussion adalah bahwa teknik ini merupakan cara yang baik untuk mengumpulkan orang-orang dari latar belakang atau pengalaman serupa untuk mendiskusikan topik tertentu yang menarik. Kelompok peserta dipandu oleh moderator (atau fasilitator kelompok) yang memperkenalkan topik untuk diskusi dan membantu kelompok untuk berpartisipasi dalam diskusi yang hidup dan alami di antara mereka sendiri.

Kekuatan FGD bergantung pada memungkinkan peserta untuk setuju atau tidak setuju satu sama lain sehingga memberikan wawasan tentang bagaimana kelompok berpikir tentang suatu masalah, tentang rentang pendapat dan ide, dan ketidakkonsistenan dan variasi yang ada dalam komunitas tertentu. dalam hal keyakinan dan pengalaman dan praktik mereka (Stewart \& Shamdasani, 1990).

FGD dapat digunakan untuk mengeksplorasi makna temuan survei yang tidak dapat dijelaskan secara statistik, berbagai pendapat / pandangan tentang suatu topik yang menarik dan untuk mengumpulkan berbagai macam istilah lokal. Dalam menjembatani penelitian dan kebijakan. Krueger (1988) menjelaskan bahwa FGD dapat berguna dalam memberikan wawasan tentang perbedaan pendapat di antara berbagai pihak yang terlibat dalam proses perubahan, sehingga memungkinkan proses untuk dikelola lebih lancar. Ini juga merupakan metode yang baik untuk digunakan sebelum mendesain kuesioner.

\section{KESIMPULAN DAN SARAN}

Berdasarkan pemaparan yang telah dilakukan sebelumnya, dapat disimpulkan bahwa terdapat berbagai pelanggaran yang jamak dilakukan andikpas selama berada di LPKA, bahkan dengan sepengetahuan petugas. Terdapat tujuh faktor yang dapat meningkatkan risiko munculnya perilaku agresi dan pelanggaran moral di LPKA, yaitu kunjungan, adu domba, suasana hati atau kondisi fisik, bercanda berlebihan, hambatan dalam menyelesaikan tugas, riwayat kehidupan sebelumnya, dan paparan terhadap seksualitas. Adapun terdapat lima faktor yang dapat mendukung munculnya perilaku agresi dan pelanggaran moral, yaitu kurangnya kontrol atau pembiaran dari petugas, contoh dari petugas, kapasitas kamar yang besar, tersedianya bahan pembuat senjata tajam, dan saling meniru sesama andikpas.

Saran untuk pengimplikasian dan tindak lanjut dari penelitian ini adalah Dari hasil kegiatan pengabdian kepada masyarakat ini didapatkan bahwa adanya factor-faktor risiko maupun factor pendukung munculnya agresi pada remaja Andikpas di LPKA Tangerang. Dari hasil FGD maka telah dilakukan analisis verbatim berdasarkan topik secara teoretik. Analisis verbatim diturunkan menjadi aitem-aitem alat ukur atau instrument yang dapat mengukur agresi remaja Andikpas. Alat ukur selanjutnya akan diteruskan dalam kajian ilmiah untuk dianalisis uji validitas dan reliabilitasnya sehingga alat ukur tersebut menjadi handal dan siap guna.

Untuk pengembangan keilmuan dalam psikologi, rencana untuk tahap berikutnya adalah pengujian pengukuran agresi andikpas dengan skala partisipan yang lebih banyak dan mencakup andikpas di wilayah lain di Indonesia.

\section{Ucapan Terima Kasih}

Penelitian ini daapt berlangsung dengan baik atas dana hibah dari Direktorat Penelitian dan Pengabdian pada MAsyarakat, Universitas Tarumanagara. 


\section{REFERENSI}

Archer, J. (2009). The Nature of Human Aggression. International Journal of Law and Psychiatry, 32, 202-208. doi:10.1016/j.ijlp.2009.04.001.

Bailey, C.A. \& Ostrov, J.M. (2008). Differentiating Forms and Functions of Aggression in Emerging Adults: Associations with Hostile Attribution Biases and Normative Beliefs. Youth Adolescence 37:713-722. DOI 10.1007/s10964-007-9211-5.

Bronfenbrenner, U. (1979). The Ecology of Human Development: Experiments By Nature And Design. The President and Fellows of Harvard College, USA

Carlo, G., Mestre, M.V., McGinley, M.M., Samper, P., Tur, A., \& Sandman, D. (2012). The interplay of emotional instability, empathy, and coping on prosocial and aggressive behaviors. Personality and Individual Differences. 53: 675-680.

Denson, T.F., Capper, M.M., Oaten, M., Friese, M., \& Schofield, T.P. (2011). Self-control training decreases aggression in response to provocation in aggressive individuals. Journal of Research in Personality. 45: 252-256.

Joefiani, P. (2013). Studi Tentang Lingkungan Sosial Dan Moral: Peran Lingkungan Keluarga, Kampus, Teman Sebaya terhadap Pengetahuan Moral, Perasaan Moral, Keteguhan Moral dalam mewujudkan Tindakan Moral Mahasiswa usia 17-23 tahun di Universitas Padjadjaran. Disertasi Universitas Padjadjaran, Bandung.

Kemp, K., Thamotharan, S., Poindexter, B., Barker, D., Tolou-Shams, M., \& Houck, C.D. (2017). Emotion Regulation As A Predictor Of Juvenile Arrest. Criminal Justice And Behavior. DOI:doi.org/10.1177/0093854817695842

Kim, Y.J. (2017). Longitudinal Relationship Between Emotion Regulation And Aggressive Behavior: The Moderating Effect Of Caregiving. Dissertation. Submitted to the Graduate Faculty of School of Social Work, University of Pittsburgh.

Krueger, R.A. (1988) Focus Groups: A practical guide for applied research. Sage, UK.

Nashriana. (2012). Perlindungan Hukum Pidana bagi Anak di Indonesia. Jakarta: Rajawali pers.

Papalia, D.E., Olds, S.W., \& Feldman, R.D. (2013). Human development (11th ed.). New York: McGraw-Hill

Stewart, D.W. and Shamdasani, P.N. (1990) Focus Groups: Theory and Practices. Sage, UK. 